\title{
Labour
}

Journal of Canadian Labour Studies

Le Travail

Revue d'Études Ouvrières Canadiennes

\section{What Have You Done for Me Lately? Back-to-Work Legislation and the Constitutional Right to Strike}

\section{Alison Braley-Rattai}

Volume 86, automne 2020

URI : https://id.erudit.org/iderudit/1074479ar

DOI : https://doi.org/10.1353/1lt.2020.0043

Aller au sommaire du numéro

Éditeur(s)

Canadian Committee on Labour History

ISSN

0700-3862 (imprimé)

1911-4842 (numérique)

Découvrir la revue

Citer cet article

Braley-Rattai, A. (2020). What Have You Done for Me Lately? Back-to-Work

Legislation and the Constitutional Right to Strike. Labour / Le Travail, 86,

148-158. https://doi.org/10.1353/llt.2020.0043 d'utilisation que vous pouvez consulter en ligne. 


\title{
What Have You Done for Me Lately? Back-to-Work Legislation and the Constitutional Right to Strike
}

\author{
Alison Braley-Rattai, Brock University
}

I HAVE TAUGHT A COURSE on the Canadian Charter of Rights and Freedoms, in one shape or form, since 2014. What I find most striking (if you'll excuse the pun) is how much faith students put into that document. Indeed, I once had a student argue in a ten-page essay that the Charter had made civil disobedience obsolete. Apparently, there were no legitimate moral claims that the Charter could not vindicate. That's some powerful document!

In 2018, I taught, for the first time, a course specifically about the constitutionalization of labour rights, that is, the use of the courts by organized labour to advance claims that specific laws - normally those that impinge upon collective bargaining or striking - violate the Charter, particularly its guarantee of freedom of association. While the use of the courts by labour is not a new phenomenon, the Charter "added an important and rapidly growing new dimension" to the study of unions and the law. ${ }^{1}$ In this course, I assigned excerpts from important case law as well as academic commentary about those cases. While we tried to make sense of what the judiciary had decided in any given case, and what the implications of that decision might be, there was a touchstone question underpinning the entire course: Had the use of a judicial strategy to advance labour rights under the Charter been successful?

Readers of this journal are likely familiar with the long-standing question among labour academics, and, indeed, some legal practitioners, as to the advisability of adopting a judicial strategy to advance labour rights. In the Charter's early years those skeptical of such a strategy - appropriately termed "Charter skeptics" - argued that the judiciary had historically been unsympathetic, if not downright hostile, to the concerns of workers and could not be expected, suddenly, to mend its ways. The first "labour cases" heard by the Supreme Court of Canada (SCC) in the Charter era appeared to vindicate their position. The SCC concluded in a trio of cases known collectively as the "labour trilogy" that the Charter protected neither the right to collectively bargain nor the right to strike. ${ }^{2}$ In an oft-cited article from 1988 commenting upon the labour trilogy, Harry Arthurs, probably the most prolific of the Charter skep-

1. Labour Law Casebook Group, Labour and Employment Law Casebook, 9th ed. (Toronto: Irwin Law 2018), 870. See also Larry Savage \& Charles W. Smith, Unions in Court (Vancouver: UBC Press, 2017), which chronicles the labour movement's disposition toward the courts, from its initial hesitance to its engagement under the Charter.

2. The trilogy comprises the following cases: Reference Re Public Service Employee Relations Act (Alta.), [1987] 1 SCR 313; RWDSU [Retail, Wholesale and Department Store Union] v Saskatchewan, [1987] 1 SCR 460; PSAC [Public Service Alliance of Canada] v Canada, [1987] 1 SCR 424 . 
tics, offered that Charter litigation was "not a game for serious people" because "serious people like a little suspense in their games." By contrast, the outcome for labour of any Charter litigation was "drearily predictable." ${ }^{3}$

But that was then, and this is now. Since that time, the SCC has done an about-face, recognizing a constitutional right to collectively bargain (in a 2007 case known as Health Services) and, in a 2015 case called Saskatchewan Federation of Labour v Saskatchewan (SFL), a right to strike! ${ }^{4}$ In so doing, the SCC overturned its labour trilogy precedent. Arthurs took the opportunity to admit that he had been mistaken - well, sort of. Acknowledging that the court had done something he had not thought at all likely - that is, recognized the "collective" dimension of freedom of association - he wrote, "The idealists were right, I must now concede, and we skeptics were wrong." ${ }^{5}$ However, he also noted that the fact of nearly 30 years of labour litigation under the Charter had done virtually nothing for the labouring class as a whole; rather, "the position of workers and unions has worsened considerably." ${ }^{6}$ Union victories in court do not lead to major legislative improvements for workers, or to a more democratic economy, as Larry Savage and Charles W. Smith note. ${ }^{7}$ By contrast, these decisions tend to be defensive in nature, doing little more than establishing a minimal constitutional bar below which legislatures may not go, as legislatures prove increasingly interested in clawing back previously extended statutory protections. ${ }^{8}$ Well ... that was then, and this is now.

In other words, it is possible that even when labour wins, it doesn't. This irony was articulated in an article that appeared in this journal on the heels of the momentous 2007 decision of the SCC to recognize a constitutional right to collectively bargain. Eric Tucker explained that the judgement to extend constitutional protection to collective bargaining was an unwitting elevation of the historical narrative of the industrial pluralists above the narrative offered by the critical labour historians, even though the work of critical labour historians had been central to the SCC's analysis. The SCC had used the work of the

3. Harry Arthurs, "The Right to Golf: Reflections on the Future of Workers, Unions and the Rest of Us under the Charter," Queen's Law Journal 13, 2 (1988): 18. For a general discussion of the early debate, see Brian Etherington, "An Assessment of Judicial Review of Labour Laws under the Charter: Of Romantics, Realists and Pragmatists," Ottawa Law Review 24, 3 (1992): 685-732; Bernie Adell, “The Queen's University Conference on Labour Law under the Charter: An Introduction to the Proceedings," Queen's Law Journal 13, 2 (1988): 5.

4. Health Services and Support - Facilities Subsector Bargaining Assn. v. British Columbia 2007 SCC 27, [2007] 2 SCR 391; Saskatchewan Federation of Labour v Saskatchewan, 2015 SCC 4, [2015] 1 SCR 245 (hereafter SFL).

5. Harry Arthurs, "Of Skeptics and Idealists: Bernie and Me and the Right to Strike," Canadian Labour and Employment Law Journal (CLELJ) 19 (2015): 327.

6. Arthurs, "Of Skeptics and Idealists," 330.

7. Savage \& Smith, Unions in Court, 210.

8. Savage \& Smith, Unions in Court, 216. 
critical labour historians to defend the proposition that collective bargaining was not a right created by modern statute. Rather, as an activity that trade unions had exercised prior to its instantiation in any modern statute, it preceded such statutes. With the aid of this new historical lens, and a variety of related arguments, the SCC recast collective bargaining as a fundamental right appropriate for constitutional protection. But in so doing, it tended to "exalt[] and constitutionalize[] a deeply flawed regime" - one given by the industrial pluralist viewpoint, even while using the work of those who had consistently criticized that viewpoint to do it. ${ }^{9}$

The test for a violation of the Charter's guarantee of associational freedom in the labour context is whether government action has "substantially interfered" with the right to collectively bargain. "Substantial interference" is a nebulous concept whose practical implications are still being worked out, most recently in Manitoba Federation of Labour et al. $v$ The Government of Manitoba. There, in a very (very) long decision of Manitoba's Queen's Bench, legislation that had been passed and had received royal assent was held to be unconstitutional, even though it had never been proclaimed.$^{10}$ Nonetheless, the legal question as to what legislative manoeuvres amount to substantial interference and which do not, is considerably less interesting than the political one: that governments might simply not care, a topic to which we shall return.

Enter, stage left, the question of the constitutional right to strike. Striking is usually thought to be the epitome of labour's power, without which the whole endeavour of meaningful collective bargaining is a charade. What, then, to make of back-to-work legislation in the context of a constitutional right to strike? In 2018, a roundtable discussion jointly sponsored by the Canadian Association for Work and Labour Studies and the Canadian Political Science Association addressed this question. The presentation I made there spawned this brief essay, which makes the following three observations: One, those who think that a constitutional right to strike offers robust protection against back-to-work legislation as a legal fact are mistaken. Two, governments will continue to restrict workers' right to strike when they determine that it is politically expedient for them to do so. However, there is a bright spot and that is that, three, meaningful arbitration as a substitute for the right to strike has been constitutionalized; this provides an avenue to resist the kind of

9. Eric Tucker, "The Constitutional Right to Bargain Collectively: The Ironies of Labour History in the Supreme Court of Canada," Labour/Le Travail 61 (Spring 2008): 151-152.

10. Manitoba Federation of Labour et al. v The Government of Manitoba, 2020 MвQв 92 (hereafter $M F L$ ). The legislation stipulated that it was to come into force on a future day fixed by proclamation, which, as of the date of the court's decision, had not yet occurred. The legislation in question was a government wage-restraint measure. By virtue of removing monetary items from the scope of bargaining, the government was held to have substantially interfered with the affected unions' right to collectively bargain - not only over monetary items but over nonmonetary ones as well. The removal of monetary items had the secondary effect of removing the union's ability to leverage monetary gains to improve upon nonmonetary gains. 
political interference in third-party adjudication that we have seen south of the border.

\section{Striking as a Narrow Right}

In order to look at the parameters of a constitutional right to strike it is helpful to say something about what a strike is, and what it is not. What counts as a strike is, of course, debatable. Charles W. Smith (in this volume) defines strike activity broadly, inclusive of any manner of activity aimed at challenging or resisting "existing social relations." This, he says, is not only because striking is historically embedded in antagonistic class relations of production between capitalist and worker but also because the crises brought about by activity that challenges these relations also lay bare the broader contradictions upon which modern capitalist societies are founded. For example, the land grab that is the Canadian colonial project historically lends a particular light with which to view "Indigenous peoples placing their bodies between their lands and colonial development projects" as strike activity as much as workers "walking off the job to pressure a recalcitrant employer."

Notably, however, in our current system of industrial legalism, strike activity is defined by statute, and quite narrowly, according to the relevant jurisdiction consistent with Canada's confederal framework. ${ }^{11}$ While the definitions vary little, they are unanimous in stating that strike activity as a matter of law is bounded by its relationship to collective bargaining. ${ }^{12}$ The constitutional benediction bestowed upon strike activity in SFL did nothing to disrupt the link between strike activity and collective bargaining, even as the majority acknowledged that some indeterminate future case may widen the parameters of strike activity worthy of constitutional protection. ${ }^{13}$

Not only are strikes currently bounded by their relationship to collective bargaining, but even within that relationship they are conceived narrowly. The relationship between strike activity and collective bargaining is not a standalone right to strike in support of collective bargaining generally, but rather consists of a right to strike so long as the strike continues to meaningfully leverage bargaining power between the parties in the context of negotiations toward a particular collective agreement. As Eric Tucker (in this volume) states, "to determine whether there has been substantial interference [with the right to strike], the court asks whether there has been a disruption of the balance between employer and employees" by the impugned action. Because

11. See, generally, Brian Langille, "What Is a Strike?" CLELJ 15 (2009/2010): 355-371.

12. We might contrast this with the comparatively wider scope of strike activity given by section 7 of the National Labor Relations Act. For a discussion, see William Corbett, "Waiting for the Labor Law of the 21st Century: Everything Old Is New Again," Berkeley Journal of Employment E Labour Law 23, 2 (2002): 259-306.

13. SFL, 2 . 
it seems far-fetched that a scenario would exist "in which a strike is no longer contributing to a meaningful process of collective bargaining," Tucker concludes that "it is likely that all [back-to-work] legislation prima facie violates Charter-protected freedom of association." This would not, of course, mean that all back-to-work legislation would be struck down, merely that it would need to be justified by reference to a section 1 analysis. I have argued much the same thing elsewhere, but with the caveat that connecting constitutional strike activity to an after-the-fact analysis as to whether the power balance has been recalibrated or disrupted in point of fact carries "the potential to increase the scope of governmental action restricting strike activity, and introduces unnecessary uncertainty in the parameters of that scope." ${ }^{14}$ In other words, while it is likely that all back-to-work legislation of otherwise legal strikes will be viewed as prima facie violations of freedom of association, it is not guaranteed. Despite the majority's consistent rhetoric of striking as indispensable to meaningful collective bargaining in $S F L$, the judiciary has appeared to reserve to itself the right to disentangle one from the other in particular instances. ${ }^{15}$

\section{Essential Services and Back-to-Work Legislation}

One of the most notable aspects of the court's decision in SFL was its discussion of "essential services." According to some early commentary on the decision, justification under section 1 would not be possible except for in the context of essential services. ${ }^{16}$ In other words, ad hoc back-to-work legislation for services that are non-essential would be struck down as a matter of course. That, however, appears not to be the case, thus further narrowing the scope of constitutionally protected strike activity.

First, it is uncontroversial that those performing essential services may be prevented from exercising any right to strike. To that end, it is not uncommon for unions and employers to be required by legislation to negotiate what are known as essential services agreements (ESAS) prior to any work stoppage. Such agreements lay out which workers perform services that should continue uninterrupted in the event of a strike or lockout. The case in $S F L$ concerned the Public Sector Essential Services Act (PSESA) passed by the Saskatchewan legislature, which mandated that unions and public employers in that province negotiate such agreements. ${ }^{17}$

14. For a further discussion, see Alison Braley-Rattai, "Canada's Statutory Strike Models and the New Constitutional Landscape," CLELJ 21, 2 (2018): 461-495.

15. SFL, at 78. See also OPSEU v Ontario, 2016 ONSC 2197, 202.

16. See, for example, Patricia McDermott, "Finally the Right to Strike: But What about Organizing?” Alternate Routes: A Journal of Critical Social Research 27 (2016): 213-223; Paul Cavalluzzo, "The Impact of Saskatchewan Federation of Labour on Future Constitutional Challenges to Restrictions on the Right to Strike," CLELJ 19, 2 (2016): 463-477.

17. Public Service Essential Services Act, ss 2008, c P-42.2, repealed by ss 2014, c 27. 
What made the legislation fundamentally unpalatable from labour's perspective is that if unions and employers could not come to terms, the legislation defaulted to the employer, allowing the employer to determine what constituted an essential service with a very limited ability for the union to challenge that determination before an impartial adjudicator. The legislation was challenged as a violation of the Charter's guarantee of freedom of association. So vast was the public employers' discretion to determine the terms of any ESA under this legislation that Justice Ball of the Saskatchewan Court of Queen's Bench claimed that "no other essential services legislation in Canada comes close to prohibiting the right to strike as broadly, and as significantly, as the $[$ PSESA]."18

The case was eventually heard by the Supreme Court of Canada. The SCC acknowledged the permissibility of preventing work stoppages in essential services, while adopting the narrow definition of "essential" proffered by the International Labour Organization (ILO), as those services where withdrawal of the service would result in a "clear and imminent threat" to "life, personal safety or health." 19 This can be distinguished from broader definitions that include considerations of an economic nature or of public inconvenience, both of which the ILO expressly rejects. In fact, the ILO's Committee on Freedom of Association reiterated its stance against the invocation of economic considerations to justify restrictions on the right to strike, in response to back-to-work legislation passed by the Canadian federal government in $2011 .^{20}$ It is these broader claims of economic exigency and public interest that underpinned a rash of back-to-work legislation at the federal level in 2011 and 2012 and that are frequently adduced by governments in the face of threatened or actual work stoppages. ${ }^{21}$

The use of back-to-work legislation to halt (or prevent) an otherwise legal work stoppage is not novel. ${ }^{22}$ As Christo Aivalis (in this volume) notes, "Trudeau's Liberal government (1968-84) was no stranger to the use of back-towork legislation" even as Pierre Trudeau favoured other means of "weakening

18. See Saskatchewan v Saskatchewan Federation of Labour, 2012, SкQв 62, 205.

19. "Right to Strike," 10.836, Compilation of Decisions of the Committee on Freedom of Association (database), International Labour Organization, accessed 6 July 2020, https://www. ilo.org/dyn/normlex/en/f?p=NORMLEXPUB:70002:0::NO::P70002_HIER_ELEMENT _ID,P70002_HIER_LEVEL:3945742,3.

20. See International Labour Office, "367th Report of the Committee on Freedom of Association,” GB.317/INS/8, Governing Body, 317th Sess., Geneva, March 2013 at paras 270-345, www.ilo.org/wcmsp5/groups/public/---ed_norm/---relconf/documents/ meetingdocument/wcms_208542.pdf.

21. See Alison Braley-Rattai, “The War on Labour: Solutions in Search of a Problem," in Teresa Healy \& Stuart Trew, eds., The Harper Record 2008-2015 (Ottawa: Canadian Centre for Policy Alternatives, 2015), 169-182.

22. See, for example, Leo Panitch \& Donald Swartz, From Consent to Coercion: The Assault on Trade Union Freedoms, 3rd ed. (Toronto: University of Toronto Press, 2003). 
the rights of unions," largely by reducing their general expectations. It is clear from SFL that any service that is truly essential may be captured by ongoing legislation preventing strikes altogether, such as commonly exists for police officers and firefighters. However, it is the ad hoc restriction upon work stoppages that are otherwise legal that is the beating heart of back-to-work legislation. The Charter right to strike has not delivered a death blow to ad hoc back-to-work legislation as some thought it might. While there is reason to believe that Charter considerations may mitigate back-to-work legislation, the Charter right to strike has certainly not prevented legislatures from passing back-to-work legislation. ${ }^{23}$ Moreover, it does not appear as if such legislation will be found unconstitutional ipso facto, even when applied to non-essential services. Justice Firestone of the Ontario Superior Court explicitly adopted this position, opining that the fact that striking may be curtailed altogether when applied to workers performing essential services did not lead ineluctably to the view that the right to strike may not be so curtailed when applied to those performing non-essential services. ${ }^{24}$

The discussion as to a service's essentiality is relevant to a section 1 analysis, even if not, in and of itself, dispositive. ${ }^{25}$ It is for this reason that it is not clear that, for instance, back-to-work legislation that ended a five-week strike in the Ontario college sector in 2017, legislation that ended a strike at Toronto's York University in 2018, or federal legislation ending a rotating strike by postal workers later that year will be found to have violated the Charter, even though both education and postal delivery are considered non-essential sectors under international labour standards.

As Charter challenges of back-to-work legislation wind their way through the courts, we will refine our understanding. However, at this point, it is fair to say that anyone who thought that constitutionalizing the right to strike was coterminous with ad hoc back-to-work legislation being ipso facto unconstitutional was probably mistaken. And that back-to-work legislation in general will likely remain a constitutionally viable option for governments, albeit subject to certain considerations that did not exist prior to SFL.

\section{The Charter and Political Expedience}

There is further bad news for those hoping that $S F L$ would provide a robust protection for a right to strike, and that is how willfully blind to the constitutional aspects of the right to strike some governments appear to be. One

23. See Alison Braley-Rattai, "Is Back-to-Work Legislation Unconstitutional?," The Conversation, 28 November 2018, https://theconversation.com/is-back-to-work-legislationunconstitutional-107561.

24. Canadian Union of Postal Workers v Canada, 2016 ONSC 418, 199-201 (hereafter CUPW).

25. For some relevant discussion, see, for example, Braley-Rattai, "Statutory Strike Models," $474-475$. 
recent example suggests itself. In September 2019, a Québec Superior Court ruled that a law passed in 2017 preventing government lawyers and notaries from striking for three years violated the Charter, primarily for the reason that the law did not provide an adequate alternative dispute-resolution mechanism. ${ }^{26}$ So far, so good.

The union, believing that the government had acted in bad faith, requested damages, claiming that the government knew the law to be unconstitutional. This request was denied. The bar for demonstrating bad faith is high, and the judge concluded that it was not met in this case. ${ }^{27}$ Evidence for this conclusion was the "concern" demonstrated for the Charter rights of the affected workers in deliberations about the law. This concern was expressed as the inclusion in the legislation of a period of continued negotiation with the possibility of mediation - but no third-party adjudication - such that bad faith could not be made out, even while the legislative measure was found to be constitutionally inadequate owing to its lack of third-party, neutral adjudication. ${ }^{28}$

According to the president of the union representing the lawyers and notaries, the decision "sends a strong signal" that back-to-work legislation must be accompanied by a meaningful mechanism for alternative dispute resolution. ${ }^{29}$ That might be heartening if it were not for the fact that $S F L$ had already sent that signal. In fact, the only "bright-line" test to come out of SFL was that whenever the right to strike is removed there must be an accompanying meaningful alternative dispute-resolution mechanism. ${ }^{30}$ At issue in the Québec case was the parties' hemming and hawing about what, specifically, makes such a mechanism "meaningful"; that such a mechanism must be present was always clear.

Whether we accept the union's view that the legislative deliberation was just for show or accept that the government genuinely believed its law would pass constitutional muster, the above demonstrates that the protection of a right to strike is less than robust. Rather, what we see are apparent legislative attempts to hew to the precise letter of the law, while exploiting the spaces left open by the judiciary's equivocations about what, specifically, the constitutional right to strike protects and what interference will, as a matter of

26. Les avocats et notaires de l'État québécois c Procureure générale du Québec, 2019 QCCS 3897 (hereafter Avocats et notaires).

27. Avocats et notaires, at 268: "Le fardeau de preuve est lourd. Laneq n'a pas démontré que le législateur s'est comporté de manière clairement fautive, a agi de mauvaise foi ou abusé de son pouvoir en adoptant la Loi 2017."

28. Avocats et notaires, $269,172-181$.

29. Luis Milan, “Court Rules Quebec Back-to-Work Legislation Unconstitutional," Lawyer's Daily, 2 October 2019, https://www.thelawyersdaily.ca/employment/articles/15645/ court-rules-quebec-s-back-to-work-legislation-unconstitutional.

30. SFL, 25. A bright-line test is a law or rule that is composed of objective factors leaving little room for interpretation. 
law, count as "substantial." Governments must contend with myriad, often opposing, interests. As well, governments may be more or less inclined toward prioritizing Charter rights, in general, or the Charter rights of workers in particular. Given that, it is not surprising that Charter rights may take a backseat altogether, in the name of political expedience. And why not, since the stakes are relatively low? Not only is back-to-work legislation not ipso facto unconstitutional, but even where legislation is found to violate the Charter, usually many years after the fact, the common remedy is a declaration of invalidity. And mere invalidity of temporal legislation makes back-to-work legislation an attractive option when dealing with a pressing labour issue. Although awards of damages are not unheard of, they remain the exception. In other words, the commonly available remedy for a violation of Charter rights is not sufficiently robust to act as a reliable deterrent, even if it were obvious that a given piece of legislation would run afoul of the Charter - and that is not always obvious.

\section{SFL and Meaningful Alternative Dispute Resolution}

After what I assume will be considered bad news by those hoping that the constitutional right to strike might have a more robust impact upon back-towork legislation than is likely, I end this essay with a bit of good news. The meaningful alternative dispute-resolution mechanism required by the SCC when the right to strike is restricted appears to be understood as independent binding arbitration - in effect, constitutionalizing as part and parcel of freedom of association the need for effective, third-party, binding adjudication in the absence of a right to strike.

I admit to thinking little of this aspect of the decision initially, since restrictions upon the statutory right to strike have been commonly - although not always - accompanied by binding arbitration. (Indeed, the legislation at issue in $S F L$ did not include recourse to binding arbitration in lieu of striking). However, government hostility toward independent adjudication of labour matters appears, increasingly, to assert itself. This elevates the importance of both the requirement of independent adjudication and what counts as "meaningful" adjudication.

Although administrative tribunals do not have independence as such, arbitrators chosen to determine the content of a collective agreement in the context of back-to-work legislation must be reasonably acceptable to both parties, that is, the employers and the unions representing affected workers. Attempts by government to sway the outcome of such adjudication through the choice of arbitrator have been forcefully rejected. The SCC determined, prior to SFL, that ministerial discretion to choose an arbitrator, even in light of statutory language that appeared to render that discretion absolute, was nonetheless tempered by the general acceptability of that choice to the parties involved. ${ }^{31}$

31. CUPE v Ontario (Minister of Labour), 2003 SCC 29, [2003] 1 SCR 539. 
That principle has been appended to the Charter when the right to strike is restricted, elevating to constitutional status the right to contest an arbitrator as reasonably rejected. ${ }^{32}$ The constitutionalization of this aspect of arbitral independence is not to be overlooked. We might usefully contrast such independence with the kind of partisan politicking that is a perennial feature of the labour relations climate in the United States. ${ }^{33}$

Closer to home, attempts to control and restrict an arbitrator's room to manoeuvre by attempting to dictate the terms of an agreement are also evident. For example, recent wage-restraint legislation from both Manitoba and Ontario contain provisions that purport to nullify arbitral decisions deemed inconsistent with the legislation even though neither statute attempted to restrict the right to strike per se. ${ }^{34}$ Manitoba's statute has since been deemed unconstitutional, and a Charter challenge has been filed in Ontario. ${ }^{35}$

Early post-SFL jurisprudence indicates that the resolution of issues that were central to any bargaining impasse may not be dictated by the government. In the words of Justice Firestone, to do so "is not a resolution to a bargaining impasse; it is the legislated abolition of a bargaining impasse." ${ }^{36}$ Given that administrative tribunals do not otherwise enjoy the formal independence of the judiciary, the constitutional requirement for meaningful third-party adjudication in the absence of a right to strike provides an avenue to resist legislative encroachment upon arbitral impartiality that would not otherwise exist. This might turn out to be the most significant aspect of $S F L$ over the long term.

\section{Conclusion}

In short, I predict that back-to-work legislation will remain constitutionally available to legislators, subject to the usual Charter analysis as to whether it is reasonably justifiable on a case-by-case basis, but that the question as to a service's essentiality, while necessary, will not be dispositive in that analysis. Moreover, because the price to pay for unconstitutional legislation is not particularly steep, governments will continue to pass legislation that they assert to be constitutional, whether they believe that to be the case or not. However, the relatively robust understanding of arbitral independence that seems to be

32. CUPW, 215-217.

33. See, for example, Samuel Estreicher, "Depoliticizing the National Labor Relations Board: Administrative Steps,” Emory Law Journal 64 (2014/2015): 1612.

34. MFL; Protecting a Sustainable Public Sector for Future Generations Act, 2019, so 2019, c 12 .

35. See Kristen Worbanski, Garth Smorang, Shannon Carson \& Joel Deeley, "Manitoba Court Finds 'Draconian' Wage Restraint Legislation Unconstitutional," Canadian Law of Work Forum (blog), 15 June 2020, http://lawofwork.ca/p12684/.

36. CUPW, 213. 
developing may yet prove useful in staving off some of the bolder manifestations of political interference, such as has been witnessed within the US labour relations climate, and to which Canada is not immune.

I would like thank Charles W. Smith for his invitation to participate in the panel discussion for which this essay was conceived. I also wish to thank the other panellists for their insightful and interesting contributions. 